\title{
LIFECYCLE COSTS COMPARATION BETWEEN DISTRICT HEATING AND INDIVIDUAL GAS HEATING
}

\author{
Dame Dimitrovski, Dalibor Stojevski \\ Faculty of Mechanical Engineering, "Ss. Cyril and Methodius" University in Skopje, \\ P.O. box 464, MK-1001, Skopje, Republic of North Macedonia \\ dame.dimitrovski@mf.edu.mk
}

\begin{abstract}
A b s tra c t: The purpose of this work is to define the economically more feasible solution to the air pollution problem in Skopje through use of district heating (DH) or individual gas heating. Suburb model is Lisiče in Skopje. Analyzed are the total lifecycle costs of entire city quarter through use of the mentioned heating types. The energy consumption and $\mathrm{CO}_{2}$ emissions from different lifecycle phases depend on the properties of pipe material, type of technologies used (during manufacturing the pipe, installing equipment and pumping technologies) and the type of fluid. Four phases are considered in this lifecycle assessment, which are production and fabrication, transportation to job site, pipe installation and operation or service phase. As can be concluded, total lifecycle costs in DH system are lower than the costs for individual gas heating. The slightly higher operating costs are annulled by the costs for maintenance and $\mathrm{CO}_{2}$, which are significantly larger by use of individual gas heating system. By use of DH system in the suburb of Lisiče, the emission of $\mathrm{PM}_{10 / 2,5}$ will be practically extinguished as the DH system uses natural gas as only source. This will lead to improved air quality in this part of Skopje.
\end{abstract}

Key words: district heating, gas heating, air pollution, heating costs

\section{СПОРЕДБА НА ТРОШОЦИТЕ ВО ТЕКОТ НА РАБОТНИОТ ВЕК НА СИСТЕМОТ ЗА ЦЕНТРАЛНО ГРЕЕЊЕ И ИНДИВИДУАЛНОТО ГРЕЕЊЕ СО ГАС}

А п с т р а к т: Целта на овој труд е да се дефинираат економски исплатливи решенија на проблемот на загадувањето на воздухот во Скопје преку анализа на системи за централно греење со гас и индивидуално загревање на објектите со гас. Како модел е земена населбата Лисиче. Во трудот се анализирани параметрите од целиот работен век на производот (услугата) за двата вида греење. Анализирани се процесите: проектирање, производство и транспорт на материјалите, вградување и работа на системот. Поради долготрајноста на системот, управувањето со отпад по завршувањето на работниот век на услугата не е земено предвид. Како што може да се заклучи, трошоците за централното греење се пониски во споредба со индивидуалното загревање со гас. Повисоките трошоци кај централниот дистрибутивен систем за топла вода се компензираат со трошоците за одржување на индивидуалните системи. Со користење централен систем за снабдување со топла вода, погонуван со природен гас, во населбата Лисиче, емисиите од системите за загревање во овој дел на градот ќе бидат нула. Па така, за очекување е дека со тоа ќе се подобри квалитетот на амбиенталниот воздух во овој дел од Скопје.

Клучни зборови: централно греење; греење на гас; загадување на воздух; трошоци за греење

\section{BACKGROUND}

Skopje is at the top of most polluted cities in the world. The situation repeats every heating season [1]. Figure 1 shows the monthly distribution of $\mathrm{PM}_{10}$ and $\mathrm{PM}_{2,5}$ in Skopje in 2017.
All relevant studies get to the conclusion that the air pollution is caused by burning wood which is most common heating by the individual households $[2,3]$.

The city quarter JI03 (Lisiče suburb) is characterized with dense structure of individual houses, 
which the highest percentage use wood in old stoves as heating source. Figure 2 shows the disposition of the Lisiče suburb. Figure 3 shows the fuels used for household heating in Skopje.

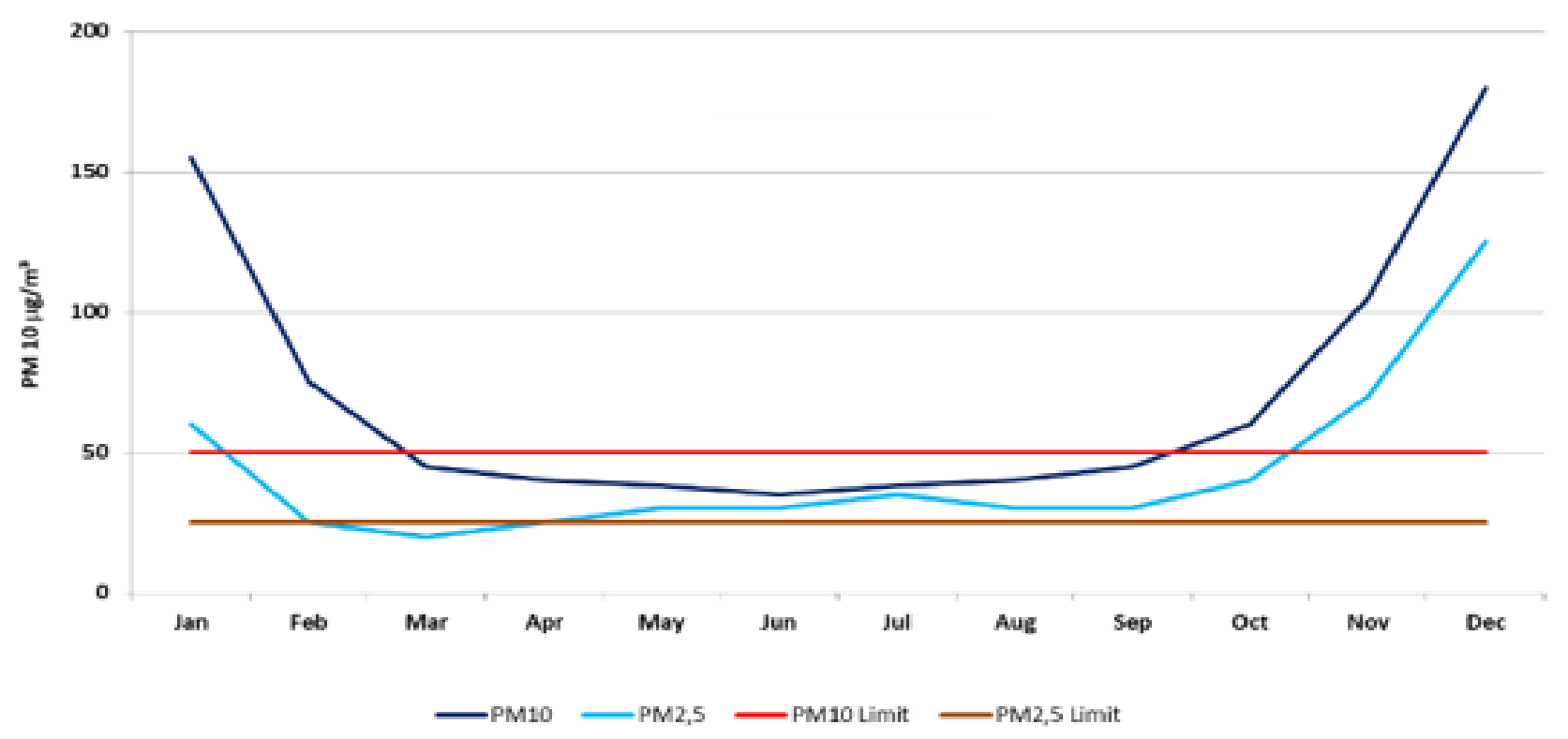

Fig. 1. Monthly distribution of $\mathrm{PM}_{10 / 2,5}$ in Skopje in 2017

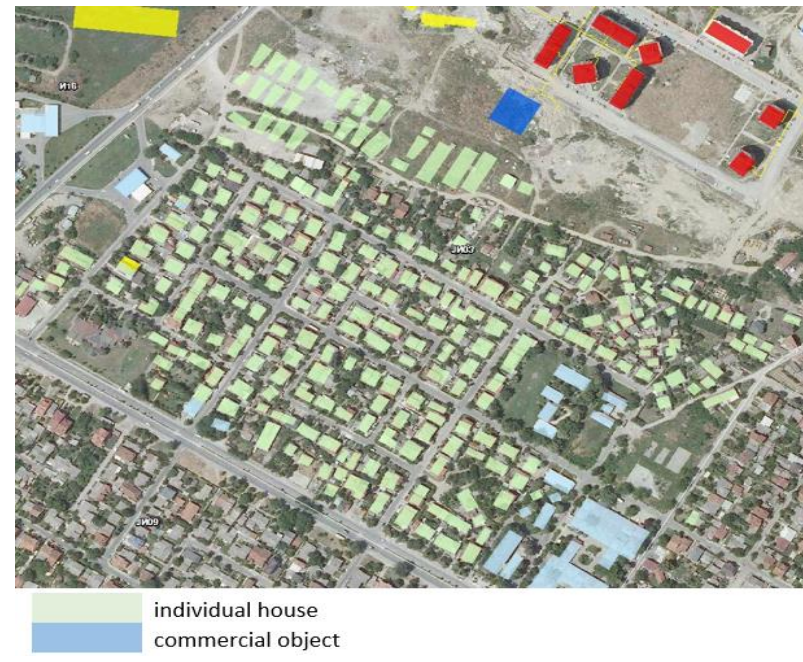

Fig. 2. Disposition of Lisiče suburb

Detail analysis was made for the entire lifecycle costs of district heating and individual gas heating.

The following costs groups were taken into calculation:

- material costs,

- installation costs,

- exploitation and maintenance costs.

All costs were summarized as a whole for the entire quarter, in order to find solution which can be

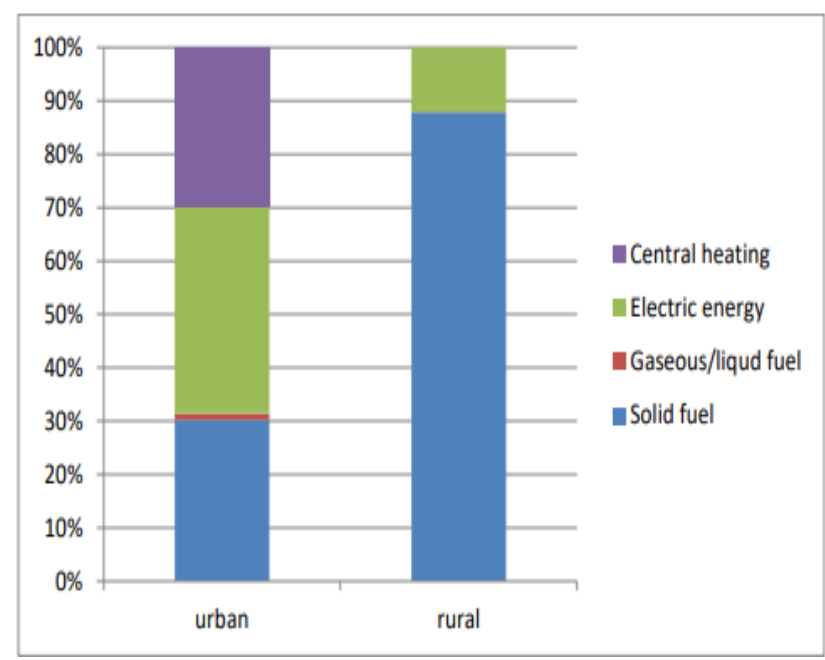

Fig. 3. Used type of heating in Skopje area

promptly initiated and can lead to the fastest solving of the air pollution problem.

\section{EXPERIMENTAL}

The Lisiče suburb is located in the eastern part of Skopje. Even though it's relative close to the city urban part, its conjuncture can be considered as rural. For getting info regarding number of objects and their heat consume, poll through the cadastre 
was made and the following type of objects were counted:

As can be viewed from the satellite view, predominantly the suburb is consisted of individual houses. According several polls, most widely used type of heating in areas with dominant individual houses is the wood heating in stoves [3]. Table 1 shows the number of objects considered in the study and the heat consume.

Table 1

\begin{tabular}{lccc}
\multicolumn{4}{c}{ Objects and heat consume } \\
\hline \hline & 1 story & 2 story & 3 story \\
\hline Number of objects & 321 & 93 & 2 \\
Heat consume $(\mathrm{kW})$ & 3624 & 2789 & 76 \\
\hline \hline
\end{tabular}

The relative age of the houses in Lisiče suburb is $>40$ years, with poor thermal insulation. In the recent years, the trend of improving the energy efficiency of the houses is obvious. Therefore, we take average thermal insulation in the calculation.

Taking into consideration the above mentioned, the following input parameters were taken into account for the heat type economic feasibility:

- Equipment is designed for heating of the whole house;

- Specific heat consume of the houses is taken as $115 \mathrm{~W} / \mathrm{m}^{2}$;

- Design room temperature is $20{ }^{\circ} \mathrm{C}$;

- Design ambient temperature is $-15^{\circ} \mathrm{C}$;

- Heating hours per year is 2745 .

\section{RESULTS AND DISCUSSION}

\section{Design of district heating system}

This part of Skopje does not have district heating $(\mathrm{DH})$ network. The main DH network under control of BEG AD is approximately $1000 \mathrm{~m}$ from the potential connection point with the conceptual secondary and connection line network in Lisiče. According design parameters (flow velocity, heat consume...), the main pipeline should be DN150. The secondary DH network should be $3 \mathrm{~km}$ ' DN80. Connection lines are $15 \mathrm{~m}^{\prime}$ at DN25. In Table 2, the prices of components used in central district heating system are shown.
Ta b le 2

Prices of components used in DH system

\begin{tabular}{|c|c|c|c|c|}
\hline & $\begin{array}{c}\text { Pipes } \\
\left(E U R / m^{\prime}\right)\end{array}$ & $\begin{array}{l}\text { Control valves } \\
\text { (EUR/piece) }\end{array}$ & $\begin{array}{l}\text { Heat meter } \\
\text { EUR/piece) }\end{array}$ & $\begin{array}{c}\text { Inner } \\
\text { installation } \\
(\mathrm{EUR} / \mathrm{kW})\end{array}$ \\
\hline DN25 & 63 & 590 & 301 & 133 \\
\hline DN32 & 74 & 826 & 413 & \\
\hline DN40 & 86 & 1.062 & 578 & \\
\hline DN50 & 98 & 2.360 & 826 & \\
\hline DN65 & 113 & 3.340 & 826 & \\
\hline DN80 & 134 & 5.310 & 1.333 & \\
\hline DN100 & 181 & I & I & \\
\hline DN150 & 262 & I & I & \\
\hline DN200 & 378 & I & I & \\
\hline
\end{tabular}

The heat station is designed as indirect, with installation of heat exchanger which separates the network medium from the indoor installation medium. Other necessary components and their costs (installation and VAT included) are:

\section{Design of individual gas system}

This part of Skopje does not have gas infrastructure. The main gas network is approximately $3000 \mathrm{~m}$ from the potential connection point with the conceptual secondary and connection line network in Lisiče.

According design parameters (flow velocity, heat consume, etc.), the main pipeline should be DN100. The secondary gas network should be HDPE DN65, while the gas connections should be G3-G10, depending of heat consume. Table 3 shows the prices of components used in individual gas system for heating.

T a b l e 3

Prices of components used in gas system

\begin{tabular}{ccc}
\hline $\begin{array}{c}\text { Capacity } \\
(\mathrm{kW})\end{array}$ & $\begin{array}{c}\text { Boiler } \\
(€)\end{array}$ & $\begin{array}{c}\text { Connecting line with GMS } \\
(€)\end{array}$ \\
\hline 24 & 770 & 1.036 \\
28 & 803 & 1.036 \\
33 & 1.306 & 1.036 \\
55 & 2.033 & 1.569 \\
85 & 3.084 & 2.369 \\
\hline \hline
\end{tabular}


Other necessary components and their costs (installation and VAT included) are: system.

- Exploitation and maintenance costs of DH

Final yearly heat need of the Lisiče suburb at 6.5 MW heat consume are 7.137 MWh. The costs towards the DH operator are as follows [5]:

-engaged heat consume - 17.863 EUR/MW/year;

-heat energy price - 35 EUR/MWh.

There is no maintenance costs in this system.

- Exploitation and maintenance costs of individual gas system.

Gas boiler efficiency is taken at $92 \%$ according low heating value [4]. This requires 814.216 $\mathrm{Nm}^{3} /$ year gas consumption.

The costs for the gas consumption are as follows:

- gas border price - $354 \mathrm{USD} / 1000 \mathrm{Nm}^{3}$;

-import costs $-2 \%$ of border price;

•trading margin - 47 EUR/1000 Nm 3 ;

- gas transmission tariff [6] - 27 EUR/1000 $\mathrm{Nm}^{3}$;

- gas distribution tariff [7] - $52 \mathrm{EUR} / 1000 \mathrm{Nm}^{3}$.

Maintenance costs are costs for inspection of the gas boiler and inner installation and cleaning of chimneys, total $60 \mathrm{EUR} /$ house.

\section{$-\mathrm{CO}_{2}$ footprint in production and installation phase of DH system [8].}

The energy consumption and $\mathrm{CO}_{2}$ emissions from different lifecycle phases depend on the properties of pipe material, type of technologies used (during manufacturing the pipe, installing equipment and pumping technologies) and the type of fluid. Four phases are considered in this lifecycle assessment, which are production and fabrication, transportation to job site, pipe installation and operation or service phase. The working period of this heating is 40 years.

\section{$-\mathrm{CO}_{2}$ footprint in production and installati-} on phase of individual gas system.

The working period of specific components of this heating varies between 10 (boilers) and 40 (pipes) years. $\mathrm{CO}_{2}$ emissions from the $\mathrm{DH}$ and gas system in the early phase are given in Table 4 and Table 5.
T a b le 4

Emission of $\mathrm{CO}_{2}$ in early phase of $\mathrm{DH}$ system

\begin{tabular}{|c|c|c|}
\hline & DN25 & DN150 \\
\hline \multicolumn{3}{|c|}{ Pipes production } \\
\hline Weight (kg/m') & 7,06 & 12.480 \\
\hline Total length (m) & 40,66 & 6.000 \\
\hline $\mathrm{CO}_{2}$ in production $(\mathrm{t})$ & 585 & 1620 \\
\hline \multicolumn{3}{|l|}{ Pipes transport } \\
\hline Distance between site and plant $(\mathrm{km})$ & 4000 & 4000 \\
\hline Max pipe sections per truck & 165 & 29 \\
\hline Total truck sessions & 6 & 17 \\
\hline Total fuel consumption (1) & 10.070 & 27.881 \\
\hline $\mathrm{CO}_{2}$ per fuel $\left(\mathrm{CO}_{2} / \mathrm{l}\right)$ & 3 & 3 \\
\hline Total $\mathrm{CO}_{2}$ for transport $(\mathrm{t})$ & 27 & 74 \\
\hline \multicolumn{3}{|l|}{ Pipes installation } \\
\hline Necessary excavation/fill hours (h) & 5.200 & 5.000 \\
\hline Fuel consumption $(1 / \mathrm{h})$ & 10 & 10 \\
\hline Total fuel consumption (1) & 52.000 & 50.000 \\
\hline $\mathrm{CO}_{2}$ per fuel $\left(\mathrm{CO}_{2} / \mathrm{l}\right)$ & 3 & 3 \\
\hline Total $\mathrm{CO}_{2}$ for installation $(\mathrm{t})$ & 154 & 148 \\
\hline
\end{tabular}

Total $\mathrm{CO}_{2}$ emission of $\mathrm{DH}$ system in early phase is $2608 \mathrm{t}$.

Table 5

Emission of $\mathrm{CO}_{2}$ in early phase of gas system

DN20 DN65 DN100

Pipes production

\begin{tabular}{lccc} 
Weight $\left(\mathrm{kg} / \mathrm{m}^{\prime}\right)$ & 0,12 & 1,05 & 3,13 \\
Total length $(\mathrm{m})$ & 6240 & 3000 & 3000 \\
$\mathrm{CO}_{2}$ in production $(\mathrm{t})$ & 11 & 45 & 134 \\
\hline
\end{tabular}

Pipes transport

\begin{tabular}{lccc} 
Distance between site and plant $(\mathrm{km})$ & 360 & 360 & 360 \\
Max pipe sections per truck & 4.000 & 378 & 176 \\
Total truck sessions & 1 & 1 & 2 \\
Total fuel consumption (l) & 144 & 144 & 288 \\
$\mathrm{CO}_{2}$ per fuel $\left(\mathrm{CO}_{2} / \mathrm{l}\right)$ & 3 & 3 & 3 \\
Total $\mathrm{CO}_{2}$ for transport (t) & 0,4 & 0,4 & 1 \\
\hline
\end{tabular}

Pipes installation

Necessary excavation/fill hours (h) $\quad \begin{array}{llll}1.560 & 1.000 & 1.250\end{array}$

Fuel consumption $(1 / \mathrm{h})$

$\begin{array}{lll}10 & 10 & 10\end{array}$

Total fuel consumption (1)

$\begin{array}{lll}15.600 & 10.000 & 12.500\end{array}$

$\mathrm{CO}_{2}$ per fuel $\left(\mathrm{CO}_{2} / \mathrm{l}\right)$

$\begin{array}{lll}3 & 3 & 3\end{array}$

Total $\mathrm{CO}_{2}$ for installation $(\mathrm{t})$

$\begin{array}{lll}46 & 30 & 37\end{array}$

Total $\mathrm{CO}_{2}$ emission of individual gas system in early phase is $303 \mathrm{t}$. 


\section{CONCLUSION}

Comparation of costs of different heating types and $\mathrm{CO}_{2}$ emissions is given in Table 6.

\section{Table 6}

\section{Lifecycle $\mathrm{CO}_{2}$ emission and cost comparison}

\begin{tabular}{lcc}
\hline \hline & $\mathrm{DH}$ & Gas \\
\hline $\begin{array}{l}\text { Total } \mathrm{CO}_{2} \text { emission in early } \\
\text { phase }\left(\mathrm{t}_{\mathrm{CO}_{2}}\right)\end{array}$ & 2608 & 303 \\
$\begin{array}{l}\text { Total } \mathrm{CO}_{2} \text { emission in } \\
\quad \text { exploitation }\left(t \mathrm{CO}_{2}\right)\end{array}$ & 16.869 & 48.623 \\
Total $\mathrm{CO}_{2}$ emission $\left(t \mathrm{CO}_{2}\right)$ & 19.477 & 48.926 \\
$\mathrm{CO}_{2}$ price $(\mathrm{EUR} / \mathrm{t})$ & 22 & 22 \\
Total $\mathrm{CO}_{2}$ costs $(\mathrm{EUR})$ & 428.500 & 1.076 .362 \\
Total investment costs (EUR) & 2.743 .463 & 3.664 .730 \\
Total operating costs (EUR) & 18.399 .652 & 18.151 .475 \\
Total maintenance costs (EUR) & - & 1.250 .000 \\
\hline Total costs (EUR) & 21.571 .615 & 24.142 .567 \\
\hline \hline
\end{tabular}

As can be concluded, total lifecycle costs in DH system are lower than the costs for individual gas heating. The slightly higher operating costs are annulled by the costs for maintenance and $\mathrm{CO}_{2}$, which are significantly larger by use of individual gas heating system.
By use of DH system in the suburb of Lisiče, the emission of $\mathrm{PM}_{10 / 2,5}$ will be practically extinguished as the DH system uses natural gas as only source. This will lead to improved air quality in this part of Skopje.

Acknowledgements. This work was supported by the colleagues from Balkan Energy Group. The authors would like to thank all of them for providing the data.

\section{REFERENCES}

[1] European Environment Agency: Air Quality in Europe, 23 (2015).

[2] Tashevski, D., Filkovski, R., Armenski, S., Dimitrovski, D., Shesho, I.: Defining techno-economic optimal and ecologic sustainable heat structure of Skopje, 59 (2017).

[3] Dimitrovski, D.: UNDP Support: Analysis of household heating practices in Skopje Valley, 2017.

[4] Or, G., Lelyveld, T., Burton, S.: Final Report: In-situ monitoring of efficiencies of condensing boilers and use of secondary heating, Prepared by: GASTEC at CRE LtdAECOM EA Technology, Prepared for: The Energy Saving Trust, Contract Number: GaC3563, June 2009.

[5] Energy Regulatory Agency of Macedonia: Decision for heat price for supply Heat Balkan Energy, 2018.

[6] Energy Regulatory Agency of Macedonia: Decision for gas transmission tariff for GA-MA, 2019.

[7] Energy Regulatory Agency of Macedonia: Decision for gas distribution tariff for Kumanovo Gas, 2019.

[8] Khan, L. R., Tee, K. F.: Quantification and comparison of carbon emissions for flexible underground pipelines, Canadian Journal of Civil Engineering, 42 (10), pp. 728736 (2015). 
